\title{
Management of cystic bony lesions at a tertiary health centre in North-West Nigeria
}

\author{
Oboirien Muhammad* and Agbo Stephen \\ Department of Surgery, Usmanu Danfodiyo University Teaching Hospital, P.M.B 2370, Sokoto, Nigeria
}

\begin{abstract}
Background: Cystic bony lesions are those that appear osteolytic on plain radiograph. It may present with painful swelling or it may be asymptomatic. The objective of this study is to determine the pattern of these lesions and outline the treatment options available in their management.

Material and methods: A retrospective study of cases of radiological cystic bony lesions managed at a tertiary health institution from 2010 to 2014 was done. Data collected were the bio data, presenting complaints, anatomical site, histologic type and treatment done.

Results: A total of 16 cases were managed with an age range of 14 years to 55 and the mean age was $27.62 \pm 11.06$. There were 10 males and 6 females and the distal femoral condyles were affected in 6 cases while there was affectation each of the fibular head 1, proximal humerus 3 and tibia 4 , distal tibia 1 and distal ulnar 1. Histology results were available in 14 cases. Giant cell tumour(GCT) was seen in 8 while aneurysmal bone cyst (ABC) was seen in 4 cases and simple bone cyst was seen in 2 cases. Treatment offered in most of the cases included curettage and irrigation with hydrogen peroxide with and without bone cement and internal fixation. Wide resection was done in 3 cases. The average follow-up was 33.6 months and recurrence occurred in one patient and complication of foot-drop was seen in another patient.
\end{abstract}

Conclusion: Cystic bony lesions are pathognomonic of benign tumours like Giant cell tumour and ABC. Curettage with or without fixation, bone graft and bone cement augmentation and wide resection are common modes of treatment.

\section{Introduction}

Cystic bony lesions are well defined bone tumours and tumour-like lesions which may be benign, malignant or it may represent some other bone conditions like osteomyelitis. The benignity or otherwise of these lesions sometimes correlates with age [1]. Pathogenesis of cystic bony lesions is still unknown and the main problem of treatment has been the high rate of recurrence sometimes in the range of $25 \%$ and $50 \%$ in some literatures $[1,2]$. Most cystic bony lesions are asymptomatic and are discovered during routine $\mathrm{x}$ rays. Some however presents with pain or attention is sometimes brought to it by trauma. The rationale for the study is to determine the common cystic lesions and the treatment options available in managing these lesions in our environment.

\section{Materials and methods}

A retrospective study of cases of radiological confirmed cystic bony lesions managed at a tertiary health institution from January 2010 and December 2014 was done. Patients who presented with history of bone pain and sometimes swelling were further evaluated with plain radiographs. Computerised tomography was also done in those who could afford. Radiolucent lytic lesion appearing in and around the metaphysis were noted as suggestive of cystic bony lesions. Cases of exophytic, fungating lesions suggesting malignant variants were excluded in the study. No preoperative histology was carried out before treatment. Lesions amenable to intralesional curettage were done through a wide cortical window taking care to avoid spillage of cyst contents. Cyst contents were subsequently sent for histology. Small defects were filled with bone graft after irrigation with hydrogen peroxide. Large defects were filled with bone cement with stabilisation and fixation using angle blade plate. Large lesions were resected completely and sent for histology. Postoperatively patients were started on graduated weight bearing and follow up for pain, function and recurrence.

\section{Results}

A total of 16 patients (10 males, 6 females) were managed with an age range of 14 to 55 years and the mean age was $27.62 \pm 11.06$. Pain was the commonest presenting symptoms followed by swelling and one patient presented with pathological fracture (Table 1). The femoral condyles were affected in 6 cases or $38 \%$ while there was affectation of the proximal tibia $4(25 \%)$, proximal humerus $3(19 \%)$, fibular head $1(6 \%)$, distal tibia $1(6 \%)$, and distal ulnar 1(6\%) (Table 2). Lesions around the knee constituted $69 \%$. Radiological features in all cases showed lytic lesion (Figures 1 and 2). Histology results were available in 14 cases. Giant cell tumour (GCT) was seen in 8 cases (50\%) and these were those involving the distal femur, distal tibia and distal ulna, while aneurysmal bone cyst $(\mathrm{ABC})$ was seen in 4 other cases involving the proximal humerus and fibular head. Treatment done included intralesional curettage and irrigation with hydrogen peroxide in 4 cases of GCT of the femoral condyle and the distal tibia lesion, while in 4 other cases of GCT of the femoral condyle, bone cement and internal fixation was done in addition to curettage (Figure 3 ). Wide resection was done

Correspondence to: Dr. Muhammad Oboirien, FWACS, Department of Surgery, Usmanu Danfodiyo University Teaching Hospital, P.M.B 2370, Sokoto, Nigeria, Tel: 234-8067893799; E-mail: moboirien@yahoo.com

Key words: cystic bony lesions, curettage, bone cement

Received: May 05, 2017; Accepted: May 15, 2017; Published: May 17, 2017 
Table 1. Study demographics.

\begin{tabular}{|c|c|c|c|c|c|c|c|c|c|}
\hline Case & Sex & Age & $\begin{array}{l}\text { Presenting } \\
\text { complaints }\end{array}$ & $\begin{array}{l}\text { Radiologic } \\
\text { features }\end{array}$ & Anatomic site & Treatment & Histology & $\begin{array}{l}\text { Follow up } \\
\text { (months) }\end{array}$ & Complications \\
\hline 1 & $\mathrm{M}$ & 30 & Pain/swelling & eccentric lesion & right distal femur & Curettage & GCT & 48 & None \\
\hline 2 & $\mathrm{~F}$ & 55 & Pain & eccentric lesion & right distal femur & Curettage/ fixation & GCT & 36 & None \\
\hline 3 & M & 28 & Pain/swelling & lytic lesion & right distal femur & Curettage/ fixation & GCT & 48 & Foot drop \\
\hline 4 & M & 34 & Pain/swelling & eccentric lesion & left proximal fibula & excision biopsy & $\mathrm{ABC}$ & 36 & None \\
\hline 5 & M & 18 & Pain/swelling & $\begin{array}{l}\text { soap bubble } \\
\text { lesion }\end{array}$ & $\begin{array}{c}\text { right proximal } \\
\text { humerus/fracture }\end{array}$ & excision biopsy & $\mathrm{ABC}$ & 12 & None \\
\hline 6 & $\mathrm{~F}$ & 28 & Pain & $\begin{array}{l}\text { radioluscent } \\
\text { lesion }\end{array}$ & right proximal tibia & Curettage & inconclusive & 48 & None \\
\hline 7 & $\mathrm{~F}$ & 32 & Swelling & $\begin{array}{l}\text { radioluscent } \\
\text { lesion }\end{array}$ & right distal ulnar & excision biopsy & GCT & 36 & None \\
\hline 8 & $\mathrm{~F}$ & 14 & Pain & $\begin{array}{l}\text { radioluscent } \\
\text { lesion }\end{array}$ & left proximal tibia & $\begin{array}{l}\text { curettage/bone } \\
\text { graft }\end{array}$ & $\mathrm{SBC}$ & 12 & None \\
\hline 9 & M & 30 & Pain/swelling & eccentric lesion & Left distal femur & Curettage & GCT & 48 & None \\
\hline 10 & $\mathrm{~F}$ & 45 & Pain & eccentric lesion & right distal femur & Curettage/ fixation & GCT & 36 & None \\
\hline 11 & M & 18 & Pain/swelling & lytic lesion & Left distal femur & Curettage/ fixation & GCT & 48 & None \\
\hline 12 & M & 24 & Pain/swelling & eccentric lesion & left proximal Humerus & excision biopsy & $\mathrm{ABC}$ & 30 & None \\
\hline 13 & M & 18 & Pain/swelling & $\begin{array}{l}\text { radioluscent } \\
\text { lesion }\end{array}$ & right proximal tibia & excision biopsy & $\mathrm{ABC}$ & 12 & None \\
\hline 14 & M & 22 & Pain & $\begin{array}{l}\text { radioluscent } \\
\text { lesion }\end{array}$ & right distal tibia & Curettage & inconclusive & 40 & None \\
\hline 15 & $\mathrm{~F}$ & 32 & Swelling & $\begin{array}{l}\text { radioluscent } \\
\text { lesion }\end{array}$ & right proxi humerus & excision biopsy & GCT & 16 & None \\
\hline \multirow[t]{2}{*}{16} & M & 14 & Pain & $\begin{array}{l}\text { radioluscent } \\
\text { lesion }\end{array}$ & left proximal tibia & $\begin{array}{c}\text { curettage/bone } \\
\text { graft }\end{array}$ & $\mathrm{SBC}$ & 32 & None \\
\hline & & Mean $27.62 \pm 11.06$ years & & & & & & 33.6 months & \\
\hline
\end{tabular}

GCT- Giant cell tumour

ABC- Aneurysmal bone cyst

SBC- Simple bone cyst

Table 2. Anatomic distribution of lesion.

\section{Chart Title}

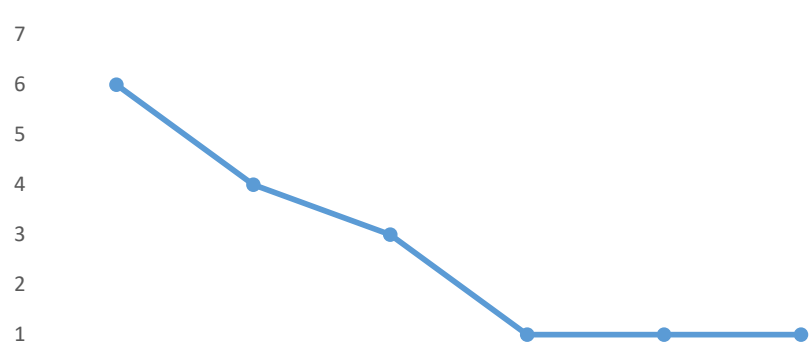

0 Distal femur Proximal tibia $\begin{gathered}\text { Proximal } \\ \text { Humerus }\end{gathered}$ Distal tibia Distal Ulnar Fibula Head

in the 3 cases of $\mathrm{ABC}$ involving the fibular head, proximal humerus. The average follow-up was 33.6 months and complication of foot-drop was seen in one patient. A case of recurrence was seen for which he had a re-operation with bone cement and fixation with implant in some other facilities.

\section{Discussion}

Cystic bone tumours and tumour-like lesions include fibrous dysplasia, aneurysmal bone cyst, Giant cell tumour (GCT), Simple bone cyst amongst others. Cystic bony lesions present commonly with pain and this may be accompanied by swelling at the affected anatomic site. When patients present early, an impression can usually be made from a plain radiograph. The sixteen cases seen over the 5year period represents those that presented early and were symptomatic. This gives a yearly incidence of 3.2 cases per year compared to a study from
National Orthopaedic Hospital, Igbobi, Lagos, Nigeria of 2 cases per year [3]. The low incidence is due to the fact that cystic bone lesions are usually benign and most are asymptomatic and are discovered accidentally. The mean age of our patients of 29.87 years is in keeping with the average age of those affected with conditions such as Giant cell tumours which are common between the second and fourth decade of life. Pain being the commonest symptoms is said to occur from build up of intraosseous pressure. Painful swelling and pathological fractures are the common indications for intervention. Radiological evaluation revealed osteolytic bony lesions with sparing of the sub-chondral bone. Clinical impression was made from the symptomatology and with the radiologic findings. Our study showed that most of the lesions occurred around the knee and this is in keeping with the findings in Igbobi, Lagos. Regions around the knee are common sites for most benign bone tumours [4,5]. This area represents the the most actively growing ends in the lower extremities.

All of the femoral condylar lesions showed a Giant cell tumour on histology. GCT is commonly seen in the distal femur, proximal tibia, proximal humerus and distal radius. It ranges from the spectrum of benign to malignant with no absolute clinical or histologic parameters to predict the biologic behaviour and is prone to recurrence $[5,6]$. Aneurysmal bone cyst was the next common lesion that appeared cystic on radiograph. It can be seen at any age but commonly in the first two decades of life and in almost any bone [7]. Histopathological examination of the bone specimen requires a trained pathologist with a bias for musculoskeletal tumours. It is not uncommon for cystic bony lesions to be labelled as inconclusive or either as GCT or ABC except in cases of obvious malignant transformation.

Management of benign cystic bony lesions depends on the clinical symptoms, location of tumour and the patients age. Treatment of 


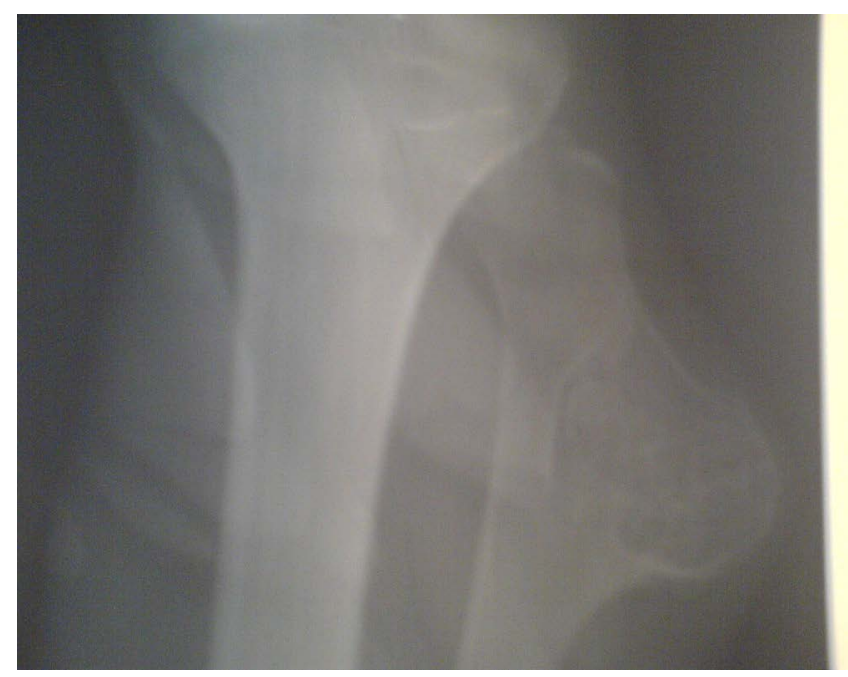

Figure 1. Lesion involving the proximal fibula.

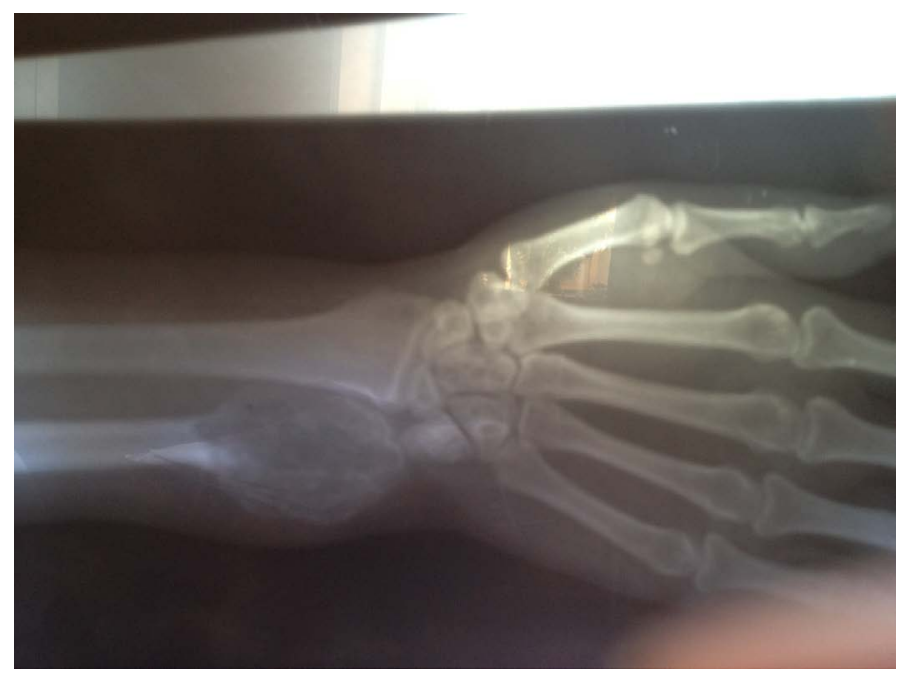

Figure 2. Lesion involving the distal ulnar.

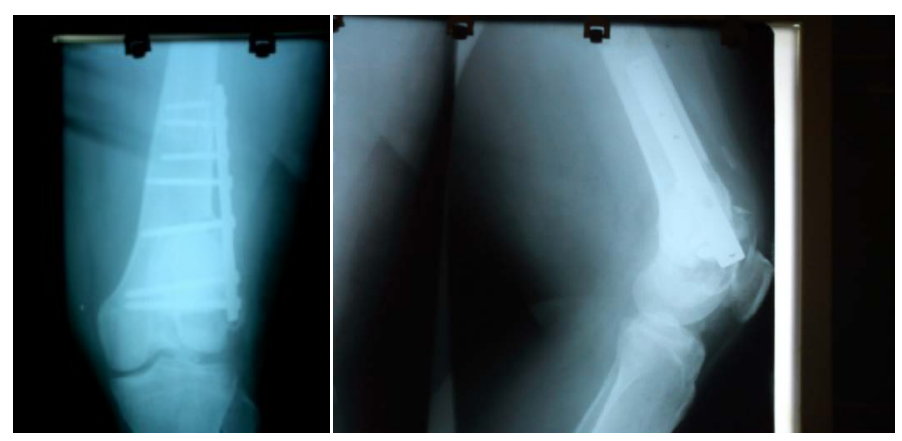

Figure 3. Xray of bone cementing and fixation of distal femoral lesion.

cystic bony lesions have evolved over time from the use of steroid injections, curettage alone, curettage with adjuvant therapy with use of liquid nitrogen, hydrogen peroxide, phenol, laser, bone graft and polymethylmethacrylate $[3,4,8]$. Other treatment modalities include marginal resection, followed by reconstruction, arthrodesis and joint replacement. In large cystic defects, augmentation with bone cement and fixation serves a pivotal role in maintaining osseous integrity and stability. Intraosseous injection of steroid especially methylprednisolone has found favourable results in about $90 \%$ with some workers [9-11].
Injection of synthetic biocompatible resorbable material has been found useful in the management of simple bone cyst and in ABC, injectable forms of calcium sulphate has been used $[12,13]$. The advantage of intralesional curettage is that it preserves the joint when compared to en bloc resection. It is however associated with a high recurrence rate especially in cases of GCT. The use of adjuvant therapy reduces the recurrence rates [14-16]. Phenol and hydrogen peroxide causes protein coagulation and necrosis and damage of the DNA $[17,18]$. Bone grafting either as auto-graft or allograft, polymethylmethacrylate can be done to restore structural integrity of the bone. In our series, small lesions were managed by simple curettage, irrigation with hydrogen peroxide and trephining of cyst in addition to cancellous bone graft. Bone cement and plate fixation was used mainly in the distal femoral condyle lesion to enhance structural integrity of the joint. Other advantages of use of bone cement is that the heating effect destroys tumour cells and also helps in the early detection of recurrence indicated by the development of lucency at the cement bone interface but it has been associated with anaphylactic reactions and degeneration of the articular cartilage $[3,19,20]$. The sandwich technique of applying a layer of bone graft and gel foam protects the articular cartilage from the thermal effect of the bone cement and also gives support to the weakened subchondral area $[4,21]$. The advantage of allograft is that it incorporates well and there is no need for removal but it makes detection of recurrence difficult. The requirement and maintenance of a bone bank is also a disadvantage [21]. The only patient that could afford a preoperative CT evaluation was the 14year old with simple bone cyst. Intraoperative findings in some patients with GCT revealed a large defect than anticipated. Bone cement therefore met the requirement of filling large tumour defects and enhancing early functional recovery. The quantity of bone cement use depends on the defect. In two of the cases we did, $40 \mathrm{~g}$ of cement was used in each of the cases. The use of oral bisphosphonase and denosumab have been use in addition to the sandwich technique to reduce the incidence of recurrence. Bisphosphonase treatment is said to reduce tumour size, induce apoptosis of osteoclast and neoplastic cells $[22,23]$. Denosumab is being tried due to its effects as a receptor activator of nuclear factor-KB ligand [24]. The complication of foot drop was from the patient that had resection of the fibular head lesion. This was iatrogenic and patient was managed with Ankle Foot Orthosis (AFO).

\section{Conclusion}

Management of cystic bony lesions depends on the histologic type, size of defect. Intralesional curettage, irrigation and augmentation with bone cement where necessary continues to remain a standard practice especially for those that present early in a resource poor setting.

\section{References}

1. Maurer F, Ambacher T, Weller S (1996) Cystic bone changes. Etiology, diagnosis, therapeutic principles and personal results of treatment. Langenbecks Arch Chir 381: 165-174. [Crossref]

2. Schaser KD, Bail HJ, Haas NP, Melcher I (2002) Treatment concepts of benign bone tumors and tumor-like bone lesions. Chirurg 73: 1181-1190. [Crossref]

3. Eyesan SU, Ugwoegbulem OA, Obalum DC (2009) Bone cement in the management of cystic tumour defects of bone at National Orthopaedic Hospital, Igbobi, Lagos. Niger J Clin Pract 12: 367-370. [Crossref]

4. Eyesan SU, Idowu OK, Obalum DC, Nnodu OE, Abdulkareem FB (2011) Surgical consideration for benign bone tumors. Niger J Clin Pract 14: 146-150. [Crossref]

5. Eckardt JJ, Grogan TJ (1986) Giant cell tumor of bone. Clin Orthop Relat Res 45-58. [Crossref]

6. Tunn PU, Schlag PM (2003) Giant cell tumor of bone. An evaluation of 87 patients. $Z$ Orthop Ihre Grenzgeb 141: 690-698. [Crossref]

7. Rapp TB, Ward JP, Alaia MJ (2012) Aneurysmal bone cyst. J Am Acad Orthop Surg 20: 233-241. [Crossref] 
8. Biermann JS (2013) Updates in the treatment of bone cancer. J Natl Compr Canc Netw 11: 681-683. [Crossref]

9. Leclet H, Adamsbaum C (1998) Intraosseous cyst injection. Radiol Clin North Am 36: 581-587. [Crossref]

10. Campanacci M, De Sessa L, Trentani C (1977) Scaglietti's method for conservative treatment of simple bone cysts with local injections of methylprednisolone acetate. Ital J Orthop Traumatol 3: 27-36. [Crossref]

11. Scaglietti O, Marchetti PG, Bartolozzi P (1982) Final results obtained in the treatment of bone cysts with methylprednisolone acetate (depo-medrol) and a discussion of results achieved in other bone lesions. Clin Orthop Relat Res 165: 33-42. [Crossref]

12. Gál P, Ondrus S, Skvaril J, Straka M, Jochymek J, Plánka L (2009) Synthetic biocompatible degradable material for juvenile bone cyst treatment. Acta Chir Orthop Traumatol Cech 76: 495-500. [Crossref]

13. Clayer M (2008) Injectable form of calcium sulphate as treatment of aneurysmal bone cysts. ANZ J Surg 78: 366-370. [Crossref]

14. Flont P, Kolacinska-Flont M, Niedzielski K (2013) A comparison of cyst wall curettage and en bloc excision in the treatment of aneurysmal bone cysts. World J Surg Oncol 11: 109. [Crossref]

15. Hunt KJ, Bergeson A, Coffin CM, Randall RL (2009) Percutaneous curettage and bone grafting for humeral simple bone cysts. Orthopedics 32: 89. [Crossref]

16. Ahmad Khan RD, Saaed UB, Zain-Ur-Rehman M, Saeed MQ, Yasin A (2015) Loca recurrence of giant cell tumour of bone after intralesional treatment with and without adjuvant therapy, a single institution case series. J Pak Med Assoc 65: S105-14. [Crossref]
17. Dürr HR, Maier M, Jansson V, Baur A, Refior HJ (1999) Phenol as an adjuvant for local control in the treatment of giant cell tumour of the bone. Eur J Surg Oncol 25: 610-618. [Crossref]

18. Lack W, Lang S, Brand G (1994) Necrotizing effect of phenol on normal tissues and on tumors. A study on postoperative and cadaver specimens. Acta Orthop Scand 65: 351-354. [Crossref]

19. Errani C, Ruggieri P, Asenzio MA, Toscano A, Colangeli S, et al. (2010) Giant cell tumor of the extremity: A review of 349 cases from a single institution. Cancer Treat Rev 36: 1-7. [Crossref]

20. Pettersson H, Rydholm A, Persson B (1986) Early radiologic detection of local recurrence after curettage and acrylic cementation of giant cell tumours. Eur J Radiol 6: 1-4. [Crossref]

21. Saibaba B, Chouhan DK, Kumar V, Dhillon MS, Rajoli SR (2014) Curettage and reconstruction by the sandwich technique for giant cell tumours around the knee. $J$ Orthop Surg (Hong Kong) 22: 351-355. [Crossref]

22. Yu X, Xu M, Xu S, Su Q (2013) Clinical outcomes of giant cell tumor of bone treated with bone cement filling and internal fixation, and oral bisphosphonates. Oncol Lett 5: 447-451. [Crossref]

23. Dufresne A, Derbel O, Cassier P, Vaz G, Decouvelaere AV, et al. (2012) Giant-cell tumor of bone, anti-RANKL therapy. Bonekey Rep 1: 149. [Crossref]

24. Panzica M, Lüke U, Omar M, Länger F, v Falck C, et al. (2014) New therapy approaches for giant cell tumors. Unfallchirurg 117: 883-891. [Crossref]

Copyright: $(2017$ Oboirien M. This is an open-access article distributed under the terms of the Creative Commons Attribution License, which permits unrestricted use, distribution, and reproduction in any medium, provided the original author and source are credited. 